\title{
Faculty development : FD
}

\section{ファカルティ・デベロップメント}

米国で家庭医療学のレジデンシーを修 了後, 指導医研修（フェローシップ）と 公衆衛生大学院を並行して修了, 2002 年 亀田メディカルセンター入職. 2006 年 6 月より家庭医療の実践, 研修, 研究の場 として開設された亀田ファミリークリ ニック館山の院長. プライマリ・ケア(家 庭医療学）の専門家，指導医養成の専門 家として活動中.

認定資格/役職：米国家庭医療学認定 委員会認定専門医 (DABFM), 米国家庭 医学会特別会員 (FAAFP), 日本プライ マリ・ケア学会認定医・認定指導医, 公 衆衛生学修士 (MMPH), 聖マリアンナ 医科大学 臨床講師, 東海大学医学部医 学科 客員准教授, 東京医科歯科大学臨 床准教授, WONCA Asia Pacific Region (世界家庭医機構) Executive Committee

\section{岡田 唯男}

米国家庭医療確立時の功労者の一人である L. Carmichael は 1967 年 に「この新しい分野はすぐに教師に対しての切実な，増大する必要性に 直面する事になる，現実的には全ての教師が臨床からひっぱりこまれ， 教育の経験のあるものはほとんどいないだろう」と述べている ${ }^{1)}$. 現在 の日本の generalist 育成の状況を予見したかの様である.

FD という用語は最近は翻訳なしでそのまま使われることが多い. 「指導医養成」が一般的に使われるが, 実際はより広い概念を含む. 最も 古い Bland $^{2)}$ の定義によると，FDの目的は「医師を医局員（faculty）の 役割につく準備をさせること」で,「所属する施設の状況や医局の中での 役割（faculty role）に応じたスキル獲得と, 現在と将来においてその人 の（構成員としての）生命力を維持する手助けをすること」と述べてお り，領域は表のように分けられている。その後の文献でもおおむね Blandのものを踏襲しており ${ }^{1,3)}$ ，共通して言えることは「医学教育（理 論と技法)」は重要ではあるがその一領域にすぎない, ということである.

generalist 育成のために臨床医としてきちんとしていること.そし て, 1 対 1 での教育スキル, 研修計画の作成などの教育能力も必要. そ れに加えて, 学部では講義や臨床実習のコマ数をより多く獲得すること や，卒後では，各科との様々な連携が欠かせない. 臨床だけの人でもコ メディカルとのチームワーク (権限委譲や恊働, 教育), 行政, 業者など との交渉などを抜きには考えられない年。筆者はFDの定義を「医育機 関において, 組織全体, およびその構成員が臨床, 教育, 研究を効果的 に行うことでその組織価值を高めるために必要な能力を学び, 高め, 維

表 1 FD がカバーすべき領域

\begin{tabular}{|c|c|c|}
\hline Bland (1990) & $\begin{array}{l}\text { Family Medicine 誌の 分 類 } \\
\text { (1997) }\end{array}$ & Harris の分類（2007） \\
\hline 1) Education & 1) Clinical Teaching Improve- & 1) Leadership \\
\hline 2) Professional Academic & ment & 2 ) Administration \\
\hline Skills & 2) Acquiring Professional & 3) Teaching (Curriculum De- \\
\hline 3) Research & Academic Skills & velopment) \\
\hline 4 ) Administration & 3 ) Developing Research Skills & 4) Research \\
\hline 5) Written Communication & $\begin{array}{l}4 \text { ) Leadership and Organiza- } \\
\text { tional Skills } \\
5 \text { ) Managing and Communi- } \\
\text { cating Information }\end{array}$ & $\begin{array}{l}\text { 5) Medical Informatics } \\
6 \text { ) Care Management } \\
\text { 7) Multiculturalism（多文化へ } \\
\text { の対応） }\end{array}$ \\
\hline
\end{tabular}

岡田唯男（おかだ ただお）

鉄蕉会 亀田ファミリークリニック館山

（＝294-0051 千葉県館山市正木 4304-9 e-mail : tadaookada+gm@gmail.com） 
持して行くための組織的および個人的な活動.」と提唱している ${ }^{5)}$. FD は指導医だけではなくある程度の年数を経た全ての医師に必要な能力で ある。

\section{文 献}

1) Dedicated Issue on Faculty Development. Family Medicine. 1997 April. vol. 29, no. 4

(家庭医療における FD の歴史, 多様な領域のカバーな ど，1冊全体が FD についての特集．包括的かつ簡潔)

2) Bland, C. J. ; Schmitz, C. C. ; Stritter, F. T. ; Henry, R. C. ; Aluise, J. J. Successful Faculty in Academic Medicine : Essential Skills and How to Acquire Them. Vol 12. New York : Springer Publishing Company, Inc ; 1990.

(一般的な大学医学部における FD について書かれた最 初でかつ最も包括的な本. 1980 年代半ばに 2 年半かけ て包括的に行なわれた調査結果に基づいており, 表の 5 つの分野を 24 の大目標とさらにその下位の 194 の Competenceに分けて, facultyのタイプによりどの能力が必 要かを設定している.)

3) Harris, D. L. et al. Academic competencies for medical faculty. Fam Med. 2007, vol. 39, no. 5, p. 343-350.

(最も最近の家庭医療における FD 領域を定義しょうと する試み。斬新で挑戦的なアイデア.)

4）岡田唯男. 医師のためのビジネス・スキルをどう学ぶか faculty development の視点から, 特集 医師のための ビジネス・スキル. JIM. 2008, vol. 18, no. 12, p. 988-
992

(医師が医学の能力だけではいかに不十分か，ではどの ような能力が必要かについて包括的に取り組んだ特集 号. 最初の総説に関わりました。 その他の執筆の多くは 後述の HANDS 関係者)

5）岡田唯男, 藤沼康樹, 杉本なお (共著)。臨床指導医養 成必携マニュアル。 ぜんにち出版株式会社. 東京. 2005.

(医学教育だけではないFDについてワークブック形式 でまとめたバインダー本. よく書かれています.)

6）岡田唯男. 17. 私のアメリカ臨床研修. II. Fellowship. J. Faculty Development, In: 佐藤隆美, 中川伸生 編著. アメリカ臨床留学への道一You can do it! 第 3 版. 南山 堂. 2005 .

(米国で FD がどのように位置づけられているか，また その能力の獲得方法や実施形態について論じています.)

7) HANDS-FDF : Home Away Nine Days Faculty Development Fellowship http://handsfdf. mywiki. biz/ (FD は医学教育だけではない, の信念のもとに, 筆者が 個人的に開催している講習会. 5 年前から始まり既に 60 名以上の修了生が各地で活躍しています.) 